\title{
Fresh, pseudotachylyte-bearing mantle peridotites from the lawsonite eclogite-facies San Petrone unit, Alpine Corsica
}

\author{
ALBERTO VITALE BROVARONE ${ }^{1,2}$, FRANCESCA \\ PICCOLI $^{3}$, GIANLUCA FRASCA ${ }^{4}$ AND FRANCESCO \\ GIUNTOLI $^{1}$ \\ ${ }^{1}$ Alma Mater Studiorum Università di Bologna \\ ${ }^{2} \mathrm{CNRS}$ \\ ${ }^{3}$ University of Bern \\ ${ }^{4}$ IGG-CNR \\ Presenting Author: alberto.vitaleb@unibo.it
}

Mantle peridotites exhumed in mountain belts provide important insights on the composition and evolution of the upper mantle, and additionally inform on metamorphic, geochemical, and tectonic processes -including seismic activities - at convergent margins. In this contribution, we present field, microstructural and mineralogical data of pseudotachylytebearing, fresh mantle peridotites from the lawsonite eclogitefacies San Petrone unit, Alpine Corsica, France. Two bodies of fresh peridotite are embedded in fully serpentinized ultramafic rocks forming the substratum of a subducted hyper-extended rifted margin of the Tethys Ocean. Thermometric estimates were obtained for the pair of mantle orthopyroxene-clinopyroxene crystals and give a crystallization temperature ranging from 950-1090 ${ }^{\circ} \mathrm{C}$ to $\sim 1010-1180{ }^{\circ} \mathrm{C}$ for a nominal pressure of 1.5 $\mathrm{GPa}$. In the pseudotachylyte, no orthopyroxene-clinopyroxene pair satisfied the test for equilibrium, suggesting fast quenching of the ultramafic melt in the pseudotachylyte. Clinopyroxene and spinel mineral chemistry indicates that the investigated peridotite samples were part of a refertilized mantle and, therefore, the San Petrone unit likely belonged to the more distal part of the hyperextended margin. The present case study represents the first example of subducted fresh peridotite associated with fresh lawsonite eclogite-facies assemblages and suggests that unaltered mantle rocks can potentially be more abundant in subduction zones than previously thought. Implications on the estimation of global abiotic $\mathrm{H}_{2}$ and $\mathrm{CH}_{4}$ fluxes and for the formation of seismic events are discussed in the final part of this contribution. 